\title{
Heterologous expression of a recombinant lactobacillal $\beta$-galactosidase in Lactobacillus plantarum: effect of different parameters on the sakacin P-based expression system
}

Tien-Thanh Nguyen ${ }^{1,2+}$, Hoang-Minh Nguyen ${ }^{1,3+}$, Barbara Geiger ${ }^{1}$, Geir Mathiesen ${ }^{4}$, Vincent GH Eijsink ${ }^{4}$, Clemens K Peterbauer', Dietmar Haltrich ${ }^{1}$ and Thu-Ha Nguyen ${ }^{1 *}$

\begin{abstract}
Background: Two overlapping genes lacL and lacM (lacLM) encoding for heterodimeric $\beta$-galactosidase from Lactobacillus reuteri were previously cloned and over-expressed in the food-grade host strain Lactobacillus plantarum WCFS1, using the inducible lactobacillal pSIP expression system. In this study, we analyzed different factors that affect the production of recombinant $L$. reuteri $\beta$-galactosidase.

Results: Various factors related to the cultivation, i.e. culture $\mathrm{pH}$, growth temperature, glucose concentration, as well as the induction conditions, including cell concentration at induction point and inducer concentration, were tested. Under optimal fermentation conditions, the maximum $\beta$-galactosidase levels obtained were $130 \mathrm{U} / \mathrm{mg}$ protein and $35-40 \mathrm{U} / \mathrm{ml}$ of fermentation broth corresponding to the formation of approximately $200 \mathrm{mg}$ of recombinant protein per litre of fermentation medium. As calculated from the specific activity of the purified enzyme (190 U/mg), $\beta$-galactosidase yield amounted to roughly $70 \%$ of the total soluble intracellular protein of the host organism. It was observed that $\mathrm{pH}$ and substrate (glucose) concentration are the most prominent factors affecting the production of recombinant $\beta$-galactosidase.

Conclusions: The over-expression of recombinant $L$. reuteri $\beta$-galactosidase in a food-grade host strain was optimized, which is of interest for applications of this enzyme in the food industry. The results provide more detailed insight into these lactobacillal expression systems and confirm the potential of the pSIP system for efficient, tightly controlled expression of enzymes and proteins in lactobacilli.
\end{abstract}

\section{Background}

Lactic acid bacteria (LAB) have been known for a long time as important micro-organisms in the preparation and processing of a wide range of different foods, beverages and animal feed [1,2]. Being capable of rapidly converting glucose to lactic acid, LAB have been used as starter cultures in the production of a number of fermented foods in e.g. the meat and dairy industries, and have thus played an important role in human nutrition.

\footnotetext{
* Correspondence: thu-ha.nguyen@boku.ac.at

${ }^{\dagger}$ Equal contributors

'Food Biotechnology Laboratory, Department of Food Science and Technology, BOKU University of Natural Resources and Life Sciences, Muthgasse 18, A-1190, Vienna, Austria

Full list of author information is available at the end of the article
}

Some lactic acid bacteria are known as producers of processing enzymes, antimicrobial peptides, or metabolites that contribute to flavor, conservation or texture of various foods. Furthermore, some LAB, in particular Lactobacillus spp., have been used as commercial probiotic cultures with health-promoting properties [2-4]. Based on their long-time use in food, a number of LAB carry the 'generally recognized as safe (GRAS)' or 'qualified presumption of safety (QPS)' status for human consumption.

In addition, LAB are increasingly considered as safe and attractive expression hosts and cell factories, especially for food-application purposes $[2,4]$. They are also attractive vehicles for in situ delivery of antigens or other bioactive compounds in the GI-tract $[5,6]$. As a consequence, a variety of constitutive or inducible gene expression and 
protein targeting systems have been developed for LAB $[2,5,7,8]$. One of the most widely used gene expression systems derived from LAB is the NIsin-Controlled gene Expression system (NICE), which is based on the autoregulatory properties and the genes involved in the synthesis of nisin, an antimicrobial peptide produced by certain strains of Lactococcus lactis [9]. The NICE system has been adapted to lactobacilli, but this approach has not always been straightforward or successful $[10,11]$. An alternative expression system, the so-called pSIP system [12], was constructed for Lactobacillus spp. based on the promoter and regulatory genes involved in the production of the class-II bacteriocins sakacin A [13] and sakacin P [14,15]. The production of these two bacteriocins is regulated via quorum sensing mechanisms that are based on secreted peptide pheromones with little or no bacteriocin activity $[5,16,17]$. The peptide pheromone (also termed inducing peptide, IP) activates a two-component regulatory system consisting of a membrane-bound histidine kinase sensing the pheromone, and an intracellular response regulator that, upon activation by the histidine kinase, induces the promoters of the operons involved in bacteriocin synthesis. In the pSIP systems, expression of the gene of interest is under control of a strong, inducible bacteriocin promoter, and gene expression is induced by external addition of the peptide pheromone. An advantage of these systems is that they are strictly regulated and lead to high production of the target protein. The applicability of these sakacin-based expression systems was shown for the over-production of enzymes such as $\beta$-glucuronidase and aminopeptidase in several Lactobacillus hosts $[7,12]$.

$\beta$-Galactosidases (lactases, EC 3.2.1.23) catalyse the hydrolysis of lactose into galactose and glucose, and are important enzymes for applications in the dairy industry [18-20]. They can among others be used to produce lowlactose or lactose-free products, or prevent crystallization of lactose especially at low temperatures [21]. Moreover, $\beta$ galactosidases can catalyse transgalactosylation reactions, transferring galactosyl moieties from e.g. lactose to a suitable acceptor molecule [18]. When lactose is the primary acceptor, galacto-oligosacharides (GOS) are obtained, which are physiologically important and health-promoting prebiotic sugars $[19,20,22,23]$. Especially $\beta$-galactosidases obtained from known probiotic bacteria such as bifidobacteria or lactobacilli are of interest for the synthesis of these prebiotic GOS [24,25]. Nguyen et al. [19] screened a number of Lactobacillus isolates and found that one strain of $L$. reuteri exhibited high $\beta$-galactosidase activity with significant transferase activity [19]. This heterodimeric $\beta$ galactosidase of $L$. reuteri is encoded by two overlapping genes, lacL and lacM. The activity levels obtained with the wild-type strain $(\sim 2.3 \mathrm{kU}$ per litre of cultivation medium, corresponding to $14 \mathrm{mg}$ of $\beta$-galactosidase protein per litre) are too low to be attractive from an applied point of view.
To improve these low yields, the coding regions of the two overlapping genes lacL and lacM (lacLM) were cloned and over-expressed in a standard expression host, Escherichia coli [26]. Heterologous expression in E. coli resulted in efficient over-expression of $\beta$-galactosidase $(\sim 110 \mathrm{kU} / \mathrm{l}$ of fermentation broth, specific activity of $55 \mathrm{U} / \mathrm{mg}$ ), yet $E$. coli might not be the preferred host for food-related enzymes. As calculated from the specific activity of the purified enzyme ( $180 \mathrm{U} / \mathrm{mg}), \beta$-galactosidase yield amounted to roughly $30 \%$ of the total soluble intracellular protein of the host organism, hence laborious chromatographic step is required for the purification of the enzyme for further applications.

We have reported the overproduction of this enzyme in the food-grade expression host Lactobacillus plantarum WCSF1 [27]. The lacLM genes from $L$. reuteri were cloned into the expression vectors pSIP403 and pSIP409, which are based on the sakacin P operon of $L$. sakei [7,12], differing only with respect to the bacteriocin promoter that drives lacLM expression ( $\mathrm{P}_{\mathrm{sppA}}$ and $\mathrm{P}_{\mathrm{sppQ}}$, respectively). This resulted in the two expression plasmids, pEH3R and pEH9R [27]. When over-expressed in the host L. plantarum WCFS1, cultivations of L. plantarum WCFS1 carrying these plasmids yielded up to $\sim 23 \mathrm{kU}$ of $\beta$-galactosidase activity, corresponding to the formation of approximately $100 \mathrm{mg}$ of recombinant protein per liter of fermentation medium, and $\beta$-galactosidase levels amounted to $55 \%$ of the total intracellular protein of the host organism [27], without any optimisation of the fermentation process. The pSIP409-derived construct pEH9R was considered the better since this construct yielded lower pheromoneindependent recombinant protein levels, indicative of a more strictly regulated promoter.

To further explore the (industrial) potential of the pSIP system in general and the use of lactobacilli for food-grade production of $\beta$-galactosidases in particular, we investigated the effects of various cultivation and induction conditions on gene expression. Among the factors studied were pheromone dose, timing of induction, culture $\mathrm{pH}$ and glucose concentration. Plasmid copy numbers during a cultivation were analyzed using reverse-transcriptase quantitative PCR. The results provide more detailed insight into these lactobacillal expression systems and show how high the expression of recombinant $L$. reuteri $\beta$-galactosidase may be achieved.

\section{Results}

Effect of inducer concentration, time of induction and glucose concentration

L. plantarum WCFS1 harbouring the plasmid pEH9R, which contains the lacLM genes under control of the pheromone-inducible $\mathrm{P}_{\mathrm{sppQ}}$ promoter, was grown with and without $\mathrm{pH}$ control under various induction conditions. The concentration of the inducing pheromone (IP; a linear 
19-residue peptide sometimes referred to as IP-673) was varied and the inducer was added at different growth phases of the host organism.

\section{Batch cultivations without $\mathrm{pH}$ control}

Cultivations were performed without $\mathrm{pH}$ control at $37^{\circ} \mathrm{C}$ using MRS medium containing $20 \mathrm{~g} / \mathrm{l}$ glucose. Despite the varying induction conditions, growth of the organism was in all cases very similar and reached an $\mathrm{OD}_{600}$ of $\sim 4.5-5.0$ after $12 \mathrm{~h}$ of cultivation (Figure 1). The volumetric activities of $\beta$-galactosidase ( $U$ per $\mathrm{ml}$ of fermentation broth) in induced cultures varied between $2 \mathrm{U} / \mathrm{ml}$ and $8 \mathrm{U} / \mathrm{ml}$, and the specific activities ranged from about $20 \mathrm{U} / \mathrm{mg}$ to $50 \mathrm{U} / \mathrm{mg}$, depending on the conditions employed. These production levels were generally reached at $\mathrm{OD}_{600} 2.0-3.0$, regardless of the time of induction (immediately after inoculation, at $\mathrm{OD}_{600}$ of $0.4-0.5$, or at $\mathrm{OD}_{600}$ of 1.5; Figure 1). The results show clear dose-response effects for the pheromone concentration, which level off at about $40 \mathrm{ng} / \mathrm{ml}$. Maximum $\beta$ galactosidase levels were quite similar for cultures induced immediately after inoculation (Figure $1 \mathrm{~A}$ ) or at an $\mathrm{OD}_{600}$ of $0.4-0.5$ (Figure $1 \mathrm{~B}$ ), but volumetric activities were clearly lower $(2-4 \mathrm{U} / \mathrm{ml}$ rather than $4-8 \mathrm{U} / \mathrm{ml})$ for cultures induced at $\mathrm{OD}_{600}$ of 1.5 (Figure 1C). These data also indicate that more pheromone is needed when induction takes place at a later growth phase. For example, induction with $20 \mathrm{ng} / \mathrm{ml}$ at $\mathrm{OD}_{600}$ of $0.4-0.5$ maximally yielded $6 \mathrm{U} / \mathrm{ml}$ and $44 \mathrm{U} / \mathrm{mg}$, whereas induction with $20 \mathrm{ng} / \mathrm{ml}$ at $\mathrm{OD}_{600}$ of 1.5 maximally yielded $2.6 \mathrm{U} / \mathrm{ml}$ and $34 \mathrm{U} / \mathrm{mg}$. In the non-induced cultures very low enzyme activity was measured with approximately $0.2 \mathrm{U} / \mathrm{ml}$ of fermentation broth or $1.3 \mathrm{U} / \mathrm{mg}$ protein (Figure $1 \mathrm{~A}$ ). The average $\mathrm{pH}$ value of the fermentation media dropped from 6.5 to approximately 5.2 or 4.3 after $7 \mathrm{~h}\left(\mathrm{OD}_{600} \sim 1.8-2.1\right)$ or $12 \mathrm{~h}\left(\mathrm{OD}_{600} \sim 4.5\right.$ 5.0) of growth, respectively.

\section{Batch cultivations with $\mathrm{pH}$ control}

In order to study the effect of the $\mathrm{pH}$ value on recombinant protein production when using the pSIP system, a series of cultivations was carried out where the $\mathrm{pH}$ was maintained at 6.5 by adding sodium hydroxide. Induction was performed using a non-saturating pheromone concentration of $20 \mathrm{ng} / \mathrm{ml}$. The results, depicted in Figure 2A, B, show that culture $\mathrm{pH}$ had a strong positive effect on both growth and protein expression, and that the time of induction (immediately after inoculation, at $\mathrm{OD}_{600}$ of 0.3 , or at $\mathrm{OD}_{600}$ of 3.0) hardly affected the outcome of the cultivations. $\mathrm{OD}_{600}$ values around 7 were reached after 10 hours of cultivation regardless of the induction time (Figure $2 \mathrm{~A}$ ) as compared to an $\mathrm{OD}_{600}$ of 4.5-5.0 obtained for growth without $\mathrm{pH}$ control (Figure 1). Accordingly, recombinant protein production was improved: $\beta$-galactosidase levels increased until the cells reached the early stationary phase to yield final volumetric activities of $15-19 \mathrm{U} / \mathrm{ml}$, which is a $2.5-3$ fold increase compared to the cultivations without $\mathrm{pH}$ control. Interestingly, specific $\beta$-galactosidase activities also increased about two-fold, reaching values of around $90-100 \mathrm{U} / \mathrm{mg}$. This indicates that the improved performance of $\mathrm{pH}$-controlled cultivations is not just a matter of increased cell densities.

Subsequently, we studied the effect of varying glucose concentrations on $\beta$-galactosidase production under $\mathrm{pH}$ controlled conditions ( $\mathrm{pH}$ 6.5). Figure 3 shows that an increase of the glucose concentration from $20 \mathrm{~g} / \mathrm{l}$ to $40 \mathrm{~g} / \mathrm{l}$ approximately doubled the maximum $\mathrm{OD}_{600}$ values, which now reached 15-18. Concomitantly, the recombinant enzyme production also increased approximately two-fold; $\beta$-galactosidase levels continuously increased during the cultivation to reach a maximum of about $35 \mathrm{U} / \mathrm{ml}$ when the stationary growth phase was reached. Maximum specific activities were only slightly higher than those obtained with $20 \mathrm{~g} / \mathrm{l}$ glucose, indicating that the increased volumetric yields are primarily caused by the increased cell densities. Dose-response effects for the pheromone were tested in a limited range only $(20-80 \mathrm{ng} / \mathrm{ml})$ and were generally small, as observed in other experiments for this concentration range. Comparison of the experiments displayed in Figure 3 further shows that under these conditions it may be favourable to induce somewhat later during growth since this yielded slightly higher specific activities. Higher concentrations of glucose $(80,120 \mathrm{~g} / \mathrm{l})$ were also tested, and this did not lead to a significant increase in enzyme yield even though higher cell densities were obtained (data not shown).

\section{Effect of antibiotic concentrations}

To examine the effect of different antibiotic concentrations on recombinant enzyme production, erythromycin concentrations of 1,5 and $10 \mu \mathrm{g} / \mathrm{ml}$ (final concentration in the cultivation medium) were tested using cultivation conditions similar to those described in Figure 3B. Varying the erythromycin concentrations had no significant effect on growth or recombinant protein production (data not shown). When no antibiotic was added to the culture medium, the $\beta$-galactosidase yield was much lower (approximately $2 \mathrm{U} / \mathrm{ml}$, data not shown) than with the antibiotic added, indicating the absolute necessity to keep the selection pressure for maintaining the expression plasmid.

\section{Effect of temperature}

Finally, we compared two different cultivation temperatures, $30^{\circ} \mathrm{C}$ and $37^{\circ} \mathrm{C}$, with respect to growth as well as over-expression of $\beta$-galactosidase. When recombinant L. plantarum WCFS1 was grown in MRS medium with $40 \mathrm{~g} / \mathrm{l}$ glucose and $\mathrm{pH}$ control at 6.5 , growth and enzyme production were faster at $37^{\circ} \mathrm{C}$ than at $30^{\circ} \mathrm{C}$. After $12 \mathrm{~h}$ 

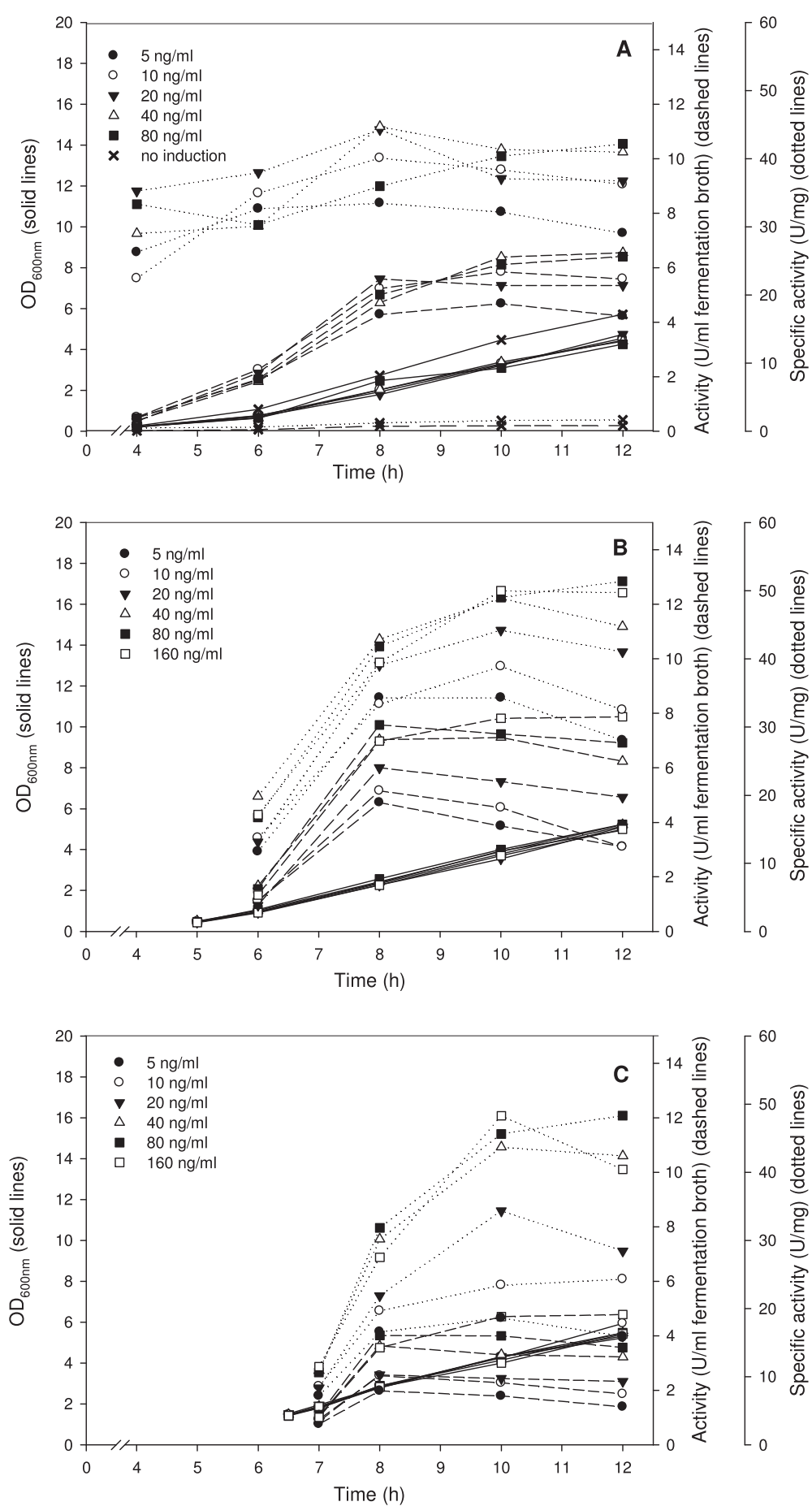

Figure 1 Time course of the cultivations of $L$. plantarum overexpressing $\beta$-galactosidase from $L$. reuteri without $\mathrm{pH}$ control. L. plantarum WCFS1 harbouring the pEH9R plasmid was grown in 50-ml cultures using MRS medium with $20 \mathrm{~g} / \mathrm{l}$ glucose, at $37^{\circ} \mathrm{C}$. Recombinant protein expression was induced by the addition of varying amounts of the inducing pheromone IP ( $\mathrm{ng} / \mathrm{ml}$ fermentation broth; see inset) at different phases of the cultivation, i.e., different $\mathrm{OD}_{600}$ values: immediately after inoculation of the culture (A), at $\mathrm{OD}_{600}$ of $0.4-0.5$ (B), or at $\mathrm{OD}_{600}$ of 1.5 (C). All data points represent the average value from 2 independent experiments.

of growth, $\mathrm{OD}_{600}$ values were approximately 17 and 10 for cultivations at $37^{\circ} \mathrm{C}$ and $30^{\circ} \mathrm{C}$, respectively (data not shown). The difference in cell densities also resulted in differences in volumetric $\beta$-galactosidase activity, which ranged from $35 \mathrm{U} / \mathrm{ml}$ for $37^{\circ} \mathrm{C}$ to $18 \mathrm{U} / \mathrm{ml}$ for $30^{\circ} \mathrm{C}$, respectively, after $12 \mathrm{~h}$. 

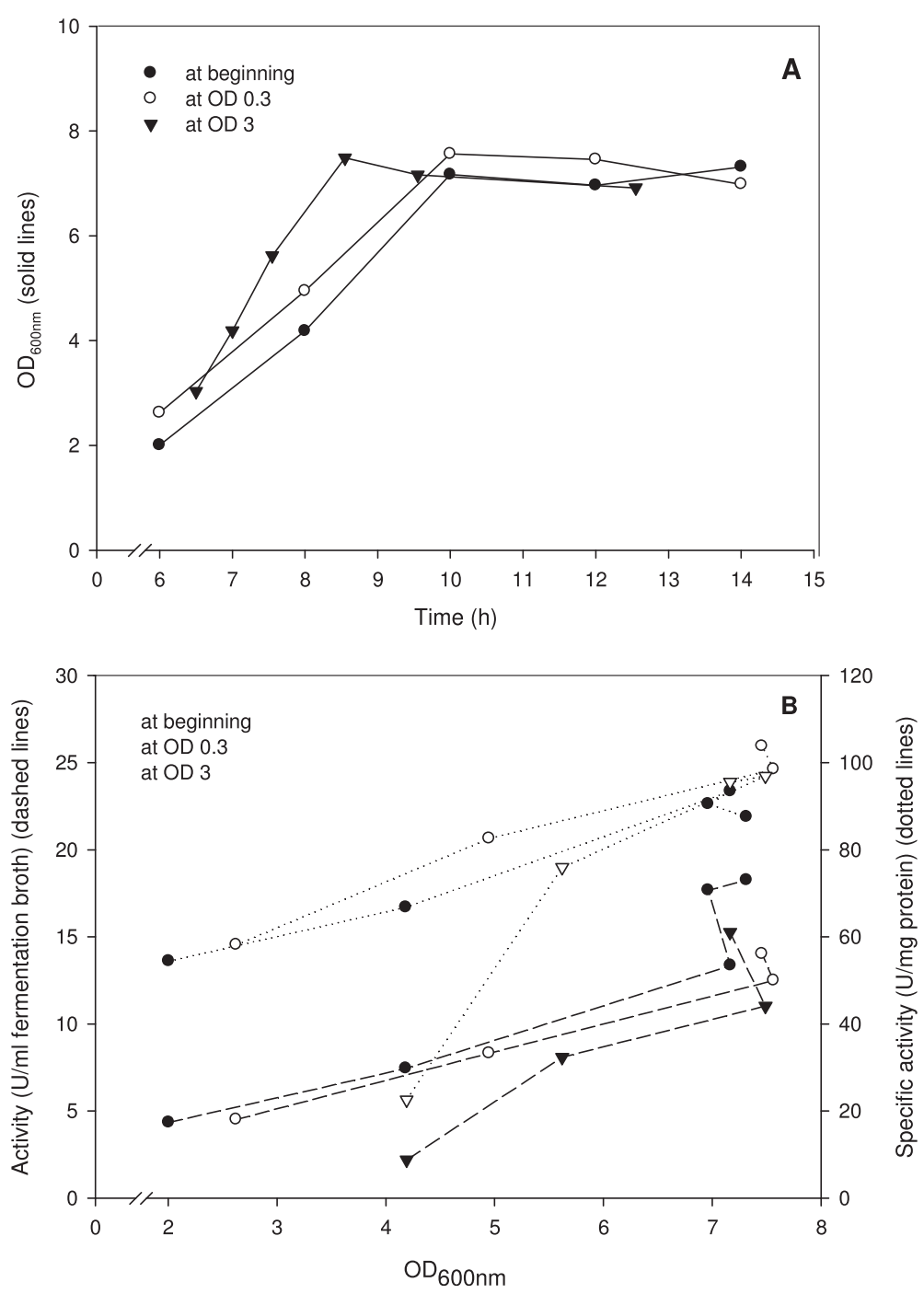

Figure 2 Effect of $\mathrm{pH}$ control on the growth (A) and enzyme production (B) of $L$. plantarum overexpressing $\beta$-galactosidase from $L$. reuteri. L. plantarum WCFS1 harbouring PEH9R was cultivated in 400-ml laboratory fermentors at $37^{\circ} \mathrm{C}$ using MRS medium with $20 \mathrm{~g} / \mathrm{l}$ glucose and $\mathrm{pH}$ control at $\mathrm{pH}$ 6.5. Expression of $\beta$-galactosidase was induced by adding $20 \mathrm{ng} / \mathrm{ml}$ pheromone at different $\mathrm{OD}_{600}$ : immediately after inoculation, at $\mathrm{OD}_{600}$ of 0.3 or at $\mathrm{OD}_{600}$ of 3.0. All data points represent the average value from 2 independent experiments.

\section{Variation of the plasmid copy number during growth}

Figure 4 shows more detailed cultivation data for an experiment run under optimal conditions. The data show that all glucose was consumed and that glucose depletion coincides with reaching maximum levels of $\beta$ galactosidase and lactic acid. To check whether the gene dose was constant during the cultivation, the plasmid copy number (PCN) was determined. The PCN was found to be at a constant level of $\sim 4$ throughout the whole exponential and stationary phase, with a slight dip in the late exponential phase.

\section{Discussion}

Progress in genetic engineering and better understanding of various regulatory mechanisms in lactobacilli have opened the perspective of engineering these bacteria to use them as microbial cell factories and delivery vehicles for proteins. The usefulness of the pSIP vector system for high protein production has previously been shown in several studies using L. plantarum and L. sakei as host strains $[7,12,27]$. Most of these studies were performed in acidifying cultures in flasks, and no detailed bioreactor studies have been performed to investigate these systems in more depth. In the present study we aimed at identifying parameters that influence heterologous protein production with the pSIP vectors by using controlled cultivation conditions, and by optimizing factors such as the time and dose of induction. We used heterodimeric $\beta$-galactosidase from $L$. reuteri, encoded by the overlapping lacLM genes, as reporter/target 

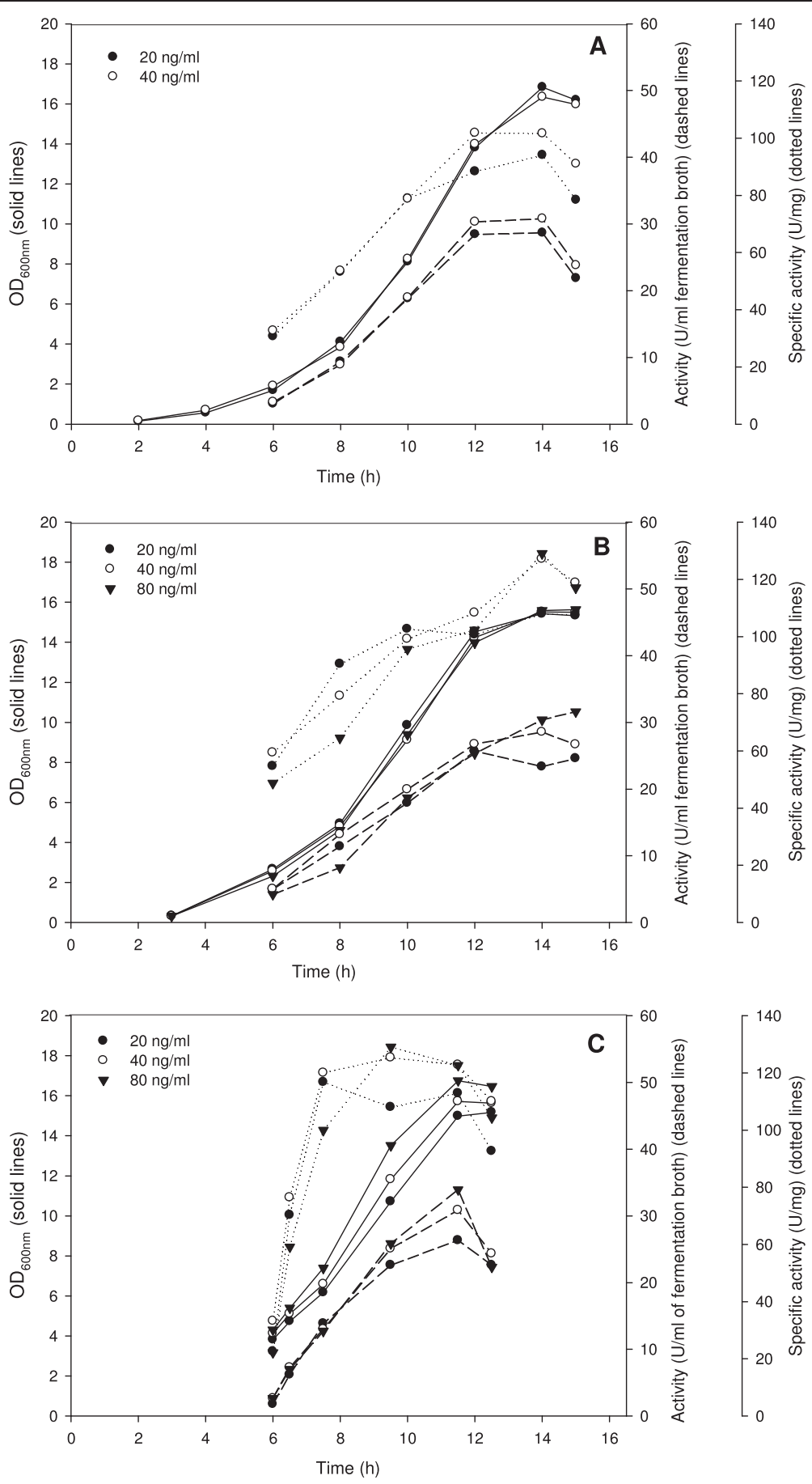

Figure 3 Time course of the cultivations of $L$. plantarum overexpressing $\beta$-galactosidase from $L$. reuteri with $\mathrm{pH}$ control at increased glucose concentration. L. plantarum WCFS1 harbouring the pEH9R plasmid was cultivated in 400-ml laboratory fermentors at $37^{\circ} \mathrm{C}$ using MRS medium with $40 \mathrm{~g} / \mathrm{l}$ glucose and $\mathrm{pH}$ control at pH 6.5. Expression of $\beta$-galactosidase was induced by the addition of varying amounts of pheromone $\left(\mathrm{ng} / \mathrm{ml}\right.$ fermentation broth; see insert) at different $\mathrm{OD}_{600}$ values: immediately after inoculation (A), at $\mathrm{OD}_{600}$ of 0.3 (B), or at $\mathrm{OD}_{600}$ of 3.0 (C). All data points represent the average value from 2 independent experiments.

protein in the optimization studies as the highest expression levels were obtained in a laboratory cultivation of $L$. plantarum WCFS 1 harbouring the plasmids containing these genes [27].
As expected the $\beta$-galactosidase yield was very low in non-induced cultures, while specific activities of up to 130 $\mathrm{U} / \mathrm{mg}$ were found under appropriate induction and growing conditions, giving typical induction factors (ratio of 


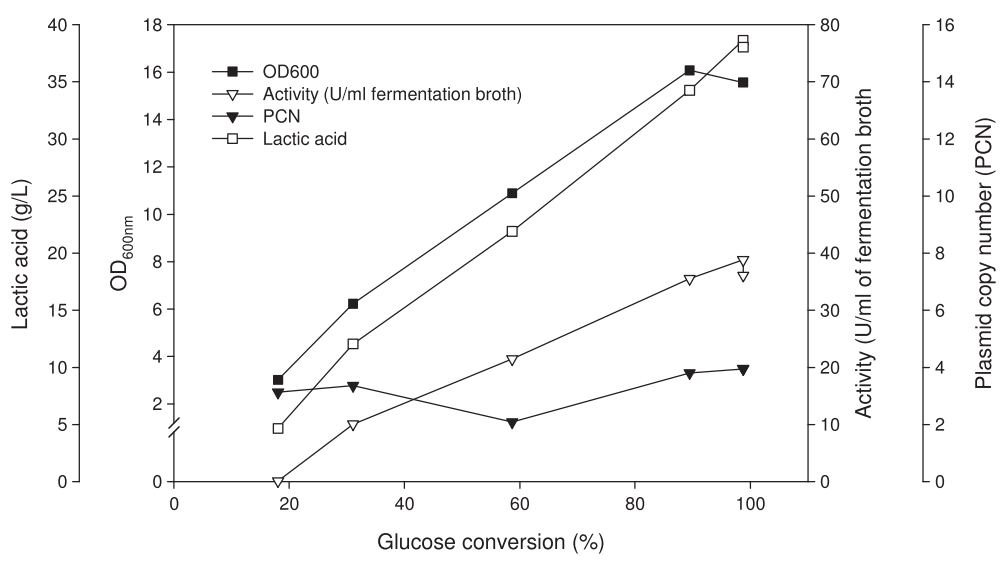

Figure 4 Variation of the plasmid copy number during the cultivations of $L$. plantarum overexpressing $\beta$-galactosidase from $L$. reuteri. L. plantarum WCFS1 harbouring the pEH9R plasmid was cultivated in $400-\mathrm{ml}$ laboratory fermentors at $37^{\circ} \mathrm{C}$ using MRS medium with $40 \mathrm{~g} / \mathrm{l}$ glucose, $\mathrm{pH}$ control at $\mathrm{pH} 6.5$ and the cells were induced at $\mathrm{OD} \sim 3$ with $80 \mathrm{ng} / \mathrm{ml}$ peptide pheromone. All data points represent the average value from 2 independent experiments.

specific activity under induced and non-induced conditions) of more than 100. This illustrates the tight control of the system, in agreement with previous studies of the pSIP expression system $[7,12]$. It should be noted that background $\beta$-galactosidase activity caused by expression of the chromosomal lacLM genes of L. plantarum are negligible $(<0.1 \mathrm{U} / \mathrm{mg})$ when the strain is grown on glucose. Hence, the activities reported in this paper can be considered as originating exclusively from heterologous expression of the vector-based lacLM genes. We observed a clear dose-response effect up to IP concentrations of $\sim 40 \mathrm{ng} / \mathrm{ml}$ (Figures 1 and 3), and none of the tested IP concentrations had inhibitory effects on growth of $L$. plantarum as is evident from the almost identical growth curves depicted in Figures 1 and 3. Apart from showing that the IP itself is not inhibitory up to the highest tested concentration of $160 \mathrm{ng} /$ $\mathrm{ml}$, this also shows that the cells are capable of handling the high amounts of heterologous protein very well.

The yield of the recombinant protein was affected by the induction time point (growth phase), but only in the experiments without $\mathrm{pH}$ control. In these experiments, induction at high optical density $\left(\mathrm{OD}_{600} \sim 1.5\right)$ resulted in lower volumetric activities than induction at low $\mathrm{OD}_{600}$, and higher pheromone concentrations were needed to reach maximum expression levels (Figure 1). The absence of this effect in cultures with $\mathrm{pH}$ control (Figures 2 and 3 ) indicates that the $\mathrm{pH}$ at the time of induction has influence on the induction efficiency, as has been suggested previously [14].

Maintaining the $\mathrm{pH}$ at a set value of 6.5 was clearly beneficial for $\beta$-galactosidase yields, both in terms of the volumetric and the specific $\beta$-galactosidase activities. This indicates that the decrease in $\mathrm{pH}$ during a non-controlled cultivation has a negative effect of the production of $\beta$ galactosidase. As expected the constant $\mathrm{pH}$ of 6.5 led to increased cell densities. However, this increase in biomass cannot solely explain the higher yields of recombinant protein, as indicated by the considerably higher specific activities that were obtained. One possible beneficial effect of the constant $\mathrm{pH}$ could be higher effectiveness of the induction process, as mentioned above. The difference in specific activities between $\mathrm{pH}$ controlled and noncontrolled fermentations was further confirmed by SDSPAGE analysis of cell free crude extract obtained from these cultivations (Figure 5), with the bands for the recombinant $\beta$-galactosidase being more prominent for the samples obtained with $\mathrm{pH}$ control.

Even higher enzyme yields were obtained when the initial glucose concentration was increased, with maximum $\beta$-galactosidase levels being reached at $40 \mathrm{~g} / \mathrm{l}$ glucose. This showed that glucose is the limiting factor in standard MRS medium. The maximum $\beta$-galactosidase levels obtained in these experiments $(130 \mathrm{U} / \mathrm{mg}$ protein and 35-40 $\mathrm{U} / \mathrm{ml}$ of fermentation broth) correspond to approximately $180 \mathrm{mg}$ of recombinant protein produced per litre of fermentation medium as calculated from the specific activity of purified enzyme of $190 \mathrm{U} / \mathrm{mg}$, which corresponds to roughly $70 \%$ of the total soluble intracellular protein being recombinant $\beta$-galactosidase. This is one of the highest expression levels obtained with gene expression systems in lactic acid bacteria to date [9].

It was previously reported that temperature can affect bacteriocin-related quorum sensing mechanisms in lactobacilli [28], and thus perhaps also expression levels for the pSIP system. We did, however, not observe significant differences in yield when comparing results at identical cell densities in $\mathrm{pH}$-controlled cultivations performed at these two temperatures.

The expression system functioned well at antibiotic concentrations down to $1 \mu \mathrm{g} / \mathrm{ml}$ but the experiments also showed that the system does not work without antibiotics 


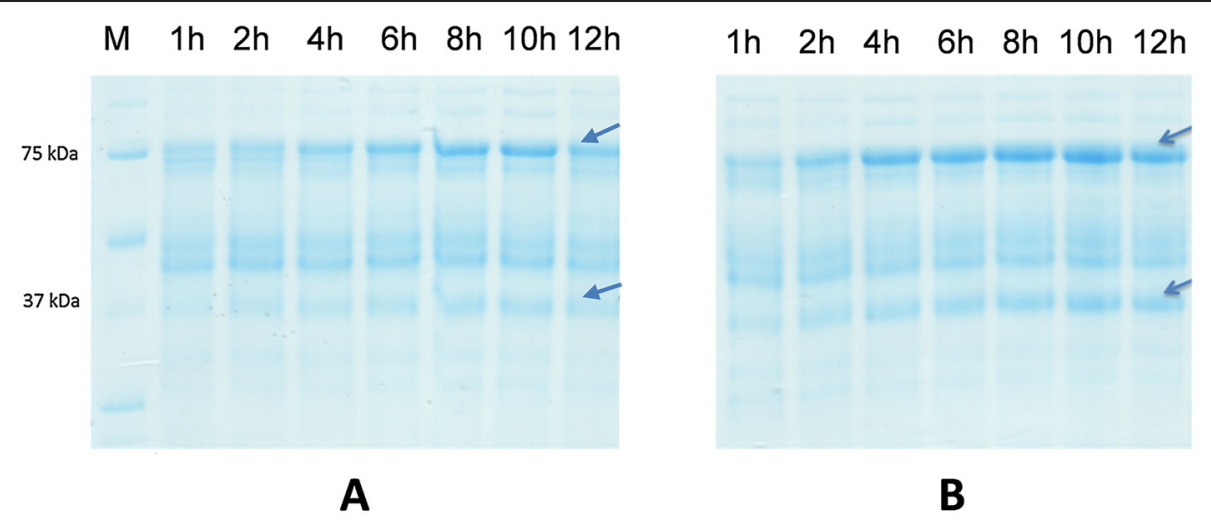

Figure 5 SDS-PAGE analysis of cell free extract of crude $L$. plantarum overexpressing $\beta$-galactosidase from $L$. reuteri from the cultivations without $\mathrm{pH}$ control (A) and with $\mathrm{pH}$ control at pH 6.5 (B). L. plantarum WCFS1 harbouring pEH9R was cultivated in 400-ml laboratory fermentors at $37^{\circ} \mathrm{C}$ using MRS medium with $20 \mathrm{~g} / \mathrm{l}$ glucose, and samples were taken at different time points. The arrows indicate the LacL and LacM subunits of the recombinant $\beta$-galactosidase. M denotes the Precision protein ladder (Biorad, CA, USA).

at all. Recent studies on segregational stability of pEH9R in L. plantarum WCFS1 showed that absence of erythromycin leads to a decrease in the number of cells harbouring plasmid pEH9R [29]. This indicates the absolute necessity to maintain strict selection pressure on the pSIP expression system during the cultivation. Because of the modular structure of the SIP system $[5,12]$ it is easy to exchange selection markers e.g. with complementation markers such as the alanine racemase gene $(a l r)[30,31]$ or the lactose carrier LacF [32], which makes the addition of antibiotics redundant. We recently developed pSIP variants based on alr as selection marker, and tests done so far indicate that these vectors perform equally well as the original ery-based vectors in terms of protein expression and stability [29].

The pEH9R plasmid was found to be present in low copy numbers (approximately 2-4, depending on the growth phase), and this is in accordance with the findings that the $256_{\text {rep }}$ replicon is a low-copy-number replicon in Lactobacillus [33]. A decrease in the PCN was observed after approx. $10 \mathrm{~h}$ of cultivation, later during the exponential growth phase. A possible explanation for this could be that because of the fast duplication of the cells during this phase of rapid growth, the cellular machinery cannot provide the daughter cell with a sufficient number of the plasmids. When the growth rate subsequently decreased again, the PCN increased to the original value of approximately 4 , and then stayed constant also during the stationary phase. It is interesting to note that the exceptionally high levels of recombinant protein, amounting to about $70 \%$ of total intracellular protein, were achieved with a gene dose not higher than approximately four.

\section{Conclusion}

We here described the optimization in terms of growth and induction conditions for the over-expression of a recombinant $\beta$-galactosidase using a pSIP409-based expression vector in Lactobacillus plantarum WCFS1. The highest $\beta$-galactosidase levels obtained were $130 \mathrm{U} / \mathrm{mg}$ protein and 35-40 U/ml of fermentation broth, which corresponds to roughly $70 \%$ of the total soluble intracellular protein being recombinant $\beta$-galactosidase.

\section{Materials and methods}

\section{Bacterial strains and media; fermentations}

L. plantarum WCFS1 [34] harbouring pEH9R [27], which contains the overlapping genes (lacLM) coding for $\beta$-galactosidase of $L$. reuteri L103 [26], was grown at $37^{\circ} \mathrm{C}$ in $5 \mathrm{ml}$ of MRS containing $5 \mu \mathrm{g} / \mathrm{ml}$ erythromycin for 16-18 h. Such overnight cultures were used as inoculum for subsequent cultivations.

For batch fermentations without $\mathrm{pH}$ control, $1 \%(\mathrm{v} / \mathrm{v})$ of inoculum was added to $50 \mathrm{ml}$ of medium, and the cultures were grown in $50 \mathrm{ml}$ tightly closed bottles at $37^{\circ} \mathrm{C}$. Batch fermentations with $\mathrm{pH}$ control were carried out in $400 \mathrm{ml}$ medium in HT-Multifors fermentors (Infors HT, Switzerland); also in this case cultures were inoculated with $1 \%(\mathrm{v} / \mathrm{v})$ of an overnight preculture. The $\mathrm{pH}$ was controlled at $\mathrm{pH} 6.5$ using sodium hydroxide when stated, and agitation was set at $200 \mathrm{rpm}$. Glucose concentrations in the MRS medium were varied as indicated. Gene expression was induced by adding varying levels of the synthetic pheromone IP-673 at different time points. IP-673 is a 19amino acid peptide synthesised commercially according to the sequence of the original pheromone from Lactobacillus sakei LTH673 [35].

Samples were taken periodically to measure optical density at $600 \mathrm{~nm}, \beta$-galactosidase activity and the PCN. For $\beta$-galactosidase measurements, cells from $1 \mathrm{ml}$ of culture were harvested by centrifugation at $16000 \mathrm{~g}$ for $3 \mathrm{~min}$, cell pellets were re-suspended in sodium phosphate buffer (buffer P) [22], and then disrupted by sonication (Bandelin 
Sonopuls HD60, Germany). Subsequently, debris was removed by centrifugation at $16000 \mathrm{~g}$ for $10 \mathrm{~min}$. The crude cell extract was used to determine $\beta$-galactosidase activity and protein concentration. For PCN estimation, an appropriate volume of sample was taken depending on the densities of the cultures $\left(\mathrm{OD}_{600}\right)$ to ensure sufficient biomass for DNA isolation. Cells were pelleted by centrifugation and stored at $-80^{\circ} \mathrm{C}$ until further use.

\section{$\beta$-Galactosidase assay}

$\beta$-Galactosidase activity was determined using $o$-nitrophenyl- $\beta$-D-galactopyranoside $(o \mathrm{NPG})$ as the substrate as described previously [19]. In brief, the assay was performed at an $o$ NPG concentration of $22 \mathrm{mM} o \mathrm{NPG}, \mathrm{pH} 6.5$, and $30^{\circ} \mathrm{C}$. One unit of $o$ NPG activity is defined as the amount of enzyme releasing $1 \mu \mathrm{mol}$ of $o \mathrm{NP}$ per minute under these conditions. Protein concentration was determined by the method of Bradford using bovine serum albumin as the standard.

\section{SDS-PAGE analysis}

The cell-free crude extracts were analysed by SDS-PAGE following the previous protocol [29]. The protein bands were stained with Coomassie Brilliant Blue G250 (Sigma, Switzerland).

\section{DNA isolation and purification for measurement of plasmid copy number (PCN)}

DNA from bacterial cells was isolated and purified using the phenol-chloroform extraction method as described previously [36]. Purified bacterial DNA was stored at $-2^{\circ} \mathrm{C}$ until further use.

\section{Quantitative reverse transcriptase PCR (qPCR) Oligonucleotide primers}

The erythromycin resistance gene $\operatorname{ermB}$ and the $16 \mathrm{~S}$ rRNA gene were chosen as representatives for plasmid DNA and genomic DNA, respectively. The oligonucleotides $\operatorname{Ery}^{\mathrm{R}}$-f, $\mathrm{Ery}^{\mathrm{R}}$-r, $16 \mathrm{~s}$-f and 16 s-r (Table 1) were used for qPCR. All primers were obtained from VBC-Biotech (Vienna, Austria).

\section{qPCR using SYBR Green I}

The thermal cycling system iCycler together with the myIQ single Color Real-Time PCR Detection system (Biorad, CA,
USA) were used for qPCR amplification and detection. The qPCR reactions were carried out in duplicates of $25-\mu \mathrm{l}$ reaction mixtures in 96-well plates (iCycler, Biorad) sealed with optical adhesive covers (Microseal 'B' film, Biorad). Each reaction contained $250 \mathrm{nM}$ of each primer, $12.5 \mu \mathrm{l}$ of Perfecta SYBR Green Super mix of IQ (Quanta Biosciences, MD, USA) and $2.5 \mu \mathrm{l}$ of template DNA (about $50 \mathrm{ng}$ ). Negative controls prepared by replacing template DNA with diethylpyrocarbonate (DEPC)-treated water, were included in each run to ensure the absence of DNA contaminants in the reagents. The concentration of primers, annealing temperature and template DNA concentrations had been optimized before the actual experiments as previously described [37]. The qPCR reactions were conducted as follows: initial denaturation at $95^{\circ} \mathrm{C}$ for $3 \mathrm{~min}$ followed by 50 cycles of $20 \mathrm{~s}$ at $95^{\circ} \mathrm{C}, 20 \mathrm{~s}$ at $60^{\circ} \mathrm{C}$, and $72^{\circ} \mathrm{C}$ for $10 \mathrm{~s}$. Fluorescence was measured at the end of each extension step at $72^{\circ} \mathrm{C}$. The temperature was increased from $55^{\circ} \mathrm{C}$ to $95^{\circ} \mathrm{C}$ at a rate of $0.2^{\circ} \mathrm{C}$ per s to establish the melting curve. The threshold cycle values $\left(\mathrm{C}_{t}\right)$ were automatically determined by MyIQ Optical System software (version 2.0) (Biorad).

\section{Calculation of the PCN value}

Based on PCN definition, which is the number of copies of a plasmid present per chromosome in bacteria $[38,39]$, the PCN can be calculated using equation (1) as previously reported [40]:

$$
P C N=\frac{E_{c} C_{t c}}{E_{p} C_{t p}}
$$

where $E_{c}, C_{t c}$ and $E_{p}, C_{t p}$ are the amplification efficiencies and the threshold cycle values of the amplicon representing chromosome and plasmid, respectively. The equivalence between the amplification efficiency $(E)$ of plasmid and chromosomal amplicons was confirmed in validation experiments as described previously [41].

\section{Validation of the reverse transcriptase PCR reaction}

A series of 10-fold dilutions of template DNA was used to run reverse transcriptase PCR reactions in order to estimate $\mathrm{C}_{\mathrm{t}}$ values and to subsequently calculate the $\Delta \mathrm{C}_{\mathrm{t}}$ values for the two primer pairs. The amplification efficiencies for

Table 1 equences of the primers used for qPCR

\begin{tabular}{|c|c|c|c|}
\hline Target gene & Primers & Sequence $\left(5^{\prime} \rightarrow 3^{\prime}\right)$ & Reference \\
\hline \multirow[t]{2}{*}{ Plasmid DNA (Erythromycin resistant gene) } & Ery $_{\text {R } f}$ & CCGTGCGTCTGACATCTATC & \multirow[t]{2}{*}{ This study } \\
\hline & Ery $^{R}{ }_{r} r$ & TGCTGAATCGAGACTTGAGTG & \\
\hline \multirow[t]{2}{*}{ Genomic DNA (16S-rRNA) } & $16 s \_f$ & TGATCCTGGCTCAGGACGAA & \multirow[t]{2}{*}{ [42] } \\
\hline & $16 s \_r$ & TGCAAGCACCAATCAATACCA & \\
\hline
\end{tabular}


the $16 \mathrm{~S}$ and Ery ${ }^{\mathrm{R}}$ primer sets calculated based on the slope of the regression lines of the plots of $\mathrm{C}_{\mathrm{t}}$ versus the logarithm of DNA dilution were found to be equivalent, i.e., 0.96 and 0.97 , respectively. This is also corroborated by the plot of $\Delta C_{t}$ versus $\log _{10}$ (DNA dilution), where a regression line with a slope of 0.04 was obtained. This indicates that the $\Delta \Delta \mathrm{C}_{\mathrm{t}}$ method can be used in this study for the two primers sets, $16 \mathrm{~S}$ and $\mathrm{Ery}^{\mathrm{R}}$ [41].

\section{High-performance liquid chromatography}

Glucose and lactic acid in fermentation samples were analyzed by high performance liquid chromatography (HPLC) using a Dionex system (Sunnyvale, CA, USA) equipped with an Aminex HPX87-H column $(300 \times 7.8 \mathrm{~mm})$ from Biorad and $0.005 \mathrm{M}$ sulphuric acid as eluent at a flow rate of $0.6 \mathrm{ml} / \mathrm{min}$, and separation temperature was at $60^{\circ} \mathrm{C}$. Interested components were detected by RID detector.

\section{Statistical analysis}

All experiments and measurements were performed at least in duplicate, and the data are given as the mean \pm standard deviation when appropriate. The standard deviation was always less than $5 \%$.

\section{Abbreviations \\ IP: Inducing pheromone; PCN: Plasmid copy number; MRS medium: de Man Rogosa and Sharpe medium; oNP: o-nitrophenol; oNPG: o-nitrophenyl- $\beta$-D- galactopyranoside.}

\section{Competing interests}

The authors declare that they have no competing interests.

\section{Authors' contributions}

TTN, THN and GM designed the experiments, TTN, HMN and BG performed the experiments, VGHE and DH conceived of the study, TTN and THN drafted the manuscript, GM, VGHE, CKP and DH contributed to the discussion, THN supervised the research and wrote the final version of the paper. All authors read and approved the final manuscript.

\section{Authors' information}

Tien-Thanh Nguyen and Hoang-Minh Nguyen: Joint first authorship.

\begin{abstract}
Acknowledgements
TTN is thankful for a 'Ernst Mach scholarship in the frame of the ASEA-Uninet granted by the OeAD - Austrian Agency for International Cooperation in Education \& Research' financed by the Austrian Federal Ministry of Science and Research and acknowledges the support from Vietnam National Foundation for Science and Technology Development (Nafosted) (Project 106.16.2011.60).. HMN thanks VIED (Vietnam International Education Development) and OeAD for financial support. HMN and BG thank for the support of the doctoral program BioToP - Biomolecular Technology of

Proteins (grant FWF-W1224) of the Austrian Science Fund (FWF). GM and VGHE acknowledge the support from the Norwegian Research Council, grant 183637. THN acknowledges the support from the Austrian Science Fund (FWF Project P24868-B22) COST Action TD1203 (EUBis) is acknowledged..
\end{abstract}

\section{Author details}

${ }^{1}$ Food Biotechnology Laboratory, Department of Food Science and Technology, BOKU University of Natural Resources and Life Sciences, Muthgasse 18, A-1190, Vienna, Austria. ${ }^{2}$ School of Biotechnology and Food Technology, Hanoi University of Science and Technology, 1 Dai Co Viet Street, Hanoi, Vietnam. ${ }^{3}$ Department of Biotechnology, Danang University of Technology, Nguyen Luong Bang 54, Danang, Vietnam. ${ }^{4}$ Department of
Chemistry, Biotechnology and Food Science, Norwegian University of Life Sciences, P.O. Box 5003, N-1432 Ás, Norway.

Received: 29 October 2014 Accepted: 20 February 2015

Published online: 07 March 2015

\section{References}

1. Collins JK, Thornton G, Sullivan GO. Selection of probiotic strains for human applications. Int Dairy J. 1998:8:487-90.

2. de-Vos WM. Gene expression systems for lactic acid bacteria. Curr Opin Microbiol. 1999;2:289-95.

3. Pouwels PH, Leer RJ. Genetics of lactobacilli: plasmids and gene expression Antonie Van Leeuwenhoek. 1993;64:85-107.

4. Kuipers OP, de Ruyter PG, Kleerebezem M, de Vos WM. Controlled overproduction of proteins by lactic acid bacteria. Trends Biotechnol. 1997;15:135-40.

5. Diep DB, Mathiesen G, Eijsink VG, Nes IF. Use of lactobacilli and their pheromone-based regulatory mechanism in gene expression and drug delivery. Curr Pharm Biotechnol. 2009;10:62-73.

6. Trombert A. Recombinant lactic acid bacteria as delivery vectors of heterologous antigens: the future of vaccination? Benef Microbes. 2014:22:1-12.

7. Sorvig E, Mathiesen G, Naterstad K, Eijsink VG, Axelsson L. High-level, inducible gene expression in Lactobacillus sakei and Lactobacillus plantarum using versatile expression vectors. Microbiology. 2005;151:2439-49.

8. de-Vos WM. Safe and sustainable systems for food - grade fermentations by genetically modified lactic acid bacteria. Int Dairy J. 1999;9:3-10.

9. Mierau I, Kleerebezem M. 10 years of the nisin-controlled gene expression system (NICE) in Lactococcus lactis. Appl Microbiol Biotechnol. 2005;68:705-17.

10. Pavan S, Hols P, Delcour J, Geoffroy MC, Grangette C, Kleerebezem M, et al. Adaptation of the nisin-controlled expression system in Lactobacillus plantarum: a tool to study in vivo biological effects. Appl Environ Microbiol. 2000;66:4427-32.

11. Wu CM, Lin CF, Chang YC, Chung RC. Construction and characterization of nisin-controlled expression vectors for use in Lactobacillus reuteri. Biosci Biotechnol Biochem. 2006;70:757-67.

12. Sorvig E, Gronqvist S, Naterstad K, Mathiesen G, Eijsink VG, Axelsson L. Construction of vectors for inducible gene expression in Lactobacillus sakei and Lactobacillus plantarum. FEMS Microbiol Lett. 2003;229:119-26.

13. Axelsson $L$, Holck $A$. The genes involved in production of and immunity to sakacin A, a bacteriocin from Lactobacillus sake Lb706. J Bacteriol. 1995:177:2125-37.

14. Brurberg MB, Nes IF, Eijsink VG. Pheromone-induced production of antimicrobial peptides in Lactobacillus. Mol Microbiol. 1997;26:347-60.

15. Huhne K, Axelsson L, Holck A, Krockel L. Analysis of the sakacin P gene cluster from Lactobacillus sake Lb674 and its expression in sakacin-negative Lb. sake strains. Microbiology. 1996;142:1437-48. Pt 6.

16. Eijsink VGH, Axelsson L, Diep DB, Havarstein LS, Holo H, Nes IF. Production of class II bacteriocins by lactic acid bacteria; an example of biological warfare and communication. Anton Leeuw Int J G Mol Microbiol. 2002:81:639-54.

17. Quadri LEN. Regulation of antimicrobial peptide production by autoinducer-mediated quorum sensing in lactic acid bacteria. Anton Leeuw Int J G Mol Microbiol. 2002;82:133-45

18. Nakayama T, Amachi T. $\beta$-galactosidase, Enzymology. In: Encyclopedia of Bioprocess Technology: Fermentation, Biocatalysis, and Bioseparation. Flickinger M, Drew Sth ed. New York: John Willey; 1999. p. 1291-305.

19. Nguyen $T H$, Splechtna $B$, Steinbock $M$, Kneifel W, Lettner HP, Kulbe KD, et al. Purification and characterization of two novel $\beta$-galactosidases from Lactobacillus reuteri. J Agric Food Chem. 2006;54:4989-98.

20. Splechtna B, Nguyen TH, Zehetner R, Lettner HP, Lorenz W, Haltrich D. Process development for the production of prebiotic galactooligosaccharides from lactose using $\beta$-galactosidase from Lactobacillus sp. Biotechnol J. 2007;2:480-5.

21. Sani RK, Chakraborti S, Sobti RC, Patnaik PR, Banerjee UC. Characterization and some reaction-engineering aspects of thermostable extracellular $\beta$-galactosidase from a new Bacillus species. Folia Microbiol (Praha). 1999;44:367-71.

22. Nguyen TH, Splechtna B, Krasteva S, Kneifel W, Kulbe KD, Divne C, et al. Characterization and molecular cloning of a heterodimeric $\beta$-galactosidase 
from the probiotic strain Lactobacillus acidophilus R22. FEMS Microbiol Lett. 2007;269:136-44.

23. Splechtna B, Nguyen TH, Steinbock M, Kulbe KD, Lorenz W, Haltrich D. Production of prebiotic galacto-oligosaccharides from lactose using $\beta$-galactosidases from Lactobacillus reuteri. J Agric Food Chem. 2006;54:4999-5006.

24. Rastall RA, Maitin V. Prebiotics and synbiotics: towards the next generation. Curr Opin Biotechnol. 2002;13:490-6.

25. Tzortzis $G$. Functional properties of the second generation prebiotic galacto-oligosaccharide (B-GOS). Agro Food Industry Hi-Tech. 2009;20:43-6.

26. Nguyen TH, Splechtna B, Yamabhai M, Haltrich D, Peterbauer C. Cloning and expression of the $\beta$-galactosidase genes from Lactobacillus reuteri in Escherichia coli. J Biotechnol. 2007;129:581-91.

27. Halbmayr E, Mathiesen G, Nguyen TH, Maischberger T, Peterbauer CK, Eijsink $V G$, et al. High-level expression of recombinant $\beta$-galactosidases in Lactobacillus plantarum and Lactobacillus sakei using a sakacin P-based expression system. J Agric Food Chem. 2008:56:4710-9.

28. Diep DB, Axelsson L, Grefsli C, Nes IF. The synthesis of the bacteriocin sakacin $A$ is a temperature-sensitive process regulated by a pheromone peptide through a three-component regulatory system. Microbiology. 2000;146(Pt 9):2155-60

29. Nguyen $\Pi$, Mathiesen $G$, Fredriksen $L$, Kittl $R$, Nguyen TH, Eijsink VGH, et al. A food-grade system for inducible gene expression in Lactobacillus plantarum using an alanine racemase-encoding selection marker. J Agric Food Chem. 2011;59:5617-24.

30. Hols P, Defrenne C, Ferain T, Derzelle S, Delplace B, Delcour J. The alanine racemase gene is essential for growth of Lactobacillus plantarum. J Bacteriol. 1997;179:3804-7.

31. Palumbo E, Favier CF, Deghorain M, Cocconcelli PS, Grangette C, Mercenier A, et al. Knockout of the alanine racemase gene in Lactobacillus plantarum results in septation defects and cell wall perforation. FEMS Microbiol Lett. 2004;233:131-8

32. Maischberger T, Mierau I, Peterbauer CK, Hugenholtz J, Haltrich D. High-level expression of Lactobacillus $\beta$-galactosidases in Lactococcus lactis using the food-grade, nisin-controlled expression system NICE. J Agric Food Chem. 2010;58:2279-87.

33. Sorvig E, Skaugen M, Naterstad K, Eijsink VG, Axelsson L. Plasmid p256 from Lactobacillus plantarum represents a new type of replicon in lactic acid bacteria, and contains a toxin-antitoxin-like plasmid maintenance system. Microbiology. 2005;151:421-31.

34. Kleerebezem M, Boekhorst J, Van Kranenburg R, Molenaar D, Kuipers OP, Leer $\mathrm{R}$, et al. Complete genome sequence of Lactobacillus plantarum WCFS1. Proc Natl Acad Sci U S A. 2003;100:1990-5.

35. Eijsink VG, Brurberg MB, Middelhoven PH, Nes IF. Induction of bacteriocin production in Lactobacillus sake by a secreted peptide. J Bacteriol. 1996;178:2232-7.

36. Pushnova EA, Geier M, Zhu YS. An easy and accurate agarose gel assay for quantitation of bacterial plasmid copy numbers. Anal Biochem. 2000;284:70-6.

37. Marco ML, Bongers RS, de Vos WM, Kleerebezem M. Spatial and temporal expression of Lactobacillus plantarum genes in the gastrointestinal tracts of mice. Appl Environ Microbiol. 2007;73:124-32.

38. Nolan T, Hands RE, Bustin SA. Quantification of mRNA using real-time RT-PCR. Nat Protoc. 2006;1:1559-82.

39. Lee $\mathrm{CL}$, Ow DS, Oh SK. Quantitative real-time polymerase chain reaction for determination of plasmid copy number in bacteria. J Microbiol Methods. 2006;65:258-67.

40. Friehs K. Plasmid copy number and plasmid stability. Adv Biochem Eng Biotechnol. 2004;86:47-82.

41. Skulj M, Okrslar V, Jalen S, Jevsevar S, Slanc P, Strukelj B, et al. Improved determination of plasmid copy number using quantitative real-time PCR for monitoring fermentation processes. Microb Cell Fact. 2008;7:6.

42. Livak KJ, Schmittgen TD. Analysis of relative gene expression data using real-time quantitative PCR and the 2 (-Delta Delta C (T)) Method. Methods. 2001;25:402-8

\section{Submit your next manuscript to BioMed Central and take full advantage of:}

- Convenient online submission

- Thorough peer review

- No space constraints or color figure charges

- Immediate publication on acceptance

- Inclusion in PubMed, CAS, Scopus and Google Scholar

- Research which is freely available for redistribution 